\title{
The Impact of Poultry Imports Liberation on Income Inequality in Indonesia
}

\author{
Firmansyah $^{1}$, Shanty Oktavilia ${ }^{2}$, Evi Yulia Purwanti ${ }^{1}$, Reikha HabibahYusfi ${ }^{3}$ \\ ${ }^{1}$ Department of Economics, Universitas Diponegoro Jl. Prof. H. Soedarto, S.H. Semarang, Jawa Tengah 50275, Indonesia \\ ${ }^{2}$ Departement of Economics, Universitas Negeri Semarang Jl. Sekaran, Gunung Pati, Semarang, Jawa Tengah 50229, \\ Indonesia \\ ${ }^{3}$ Student of Master of Economics and Development Studies, Universitas Diponegoro Jl. Imam Bardjo No.2, Semarang, \\ Jawa Tengah 50241, Indonesia
}

\begin{abstract}
Livestock is one of the sectors that has great contribution to the national economy and absorbs labor force significantly; by about 4.24 million households are looking for livelihoods in this sector. By the possibility of liberation of poultry imports, such as Brazil's success on dispute of Indonesian poultry imports in the WTO, it isestimated that the income level of the worker in the poultry sector will be disrupted. By employing the Input-Output and Social Accounting Matrices analysis, this study simulates and analyses the impact of poultry import liberation on households' income in Indonesia. The results show that the domestic consumptionsare affected by the imports due to tariff reductions and will further affect the national and sectoral domestic output. The low levels income households who work in agriculture and live in rural areas receive a greater impact of income decrease than urban households, while non-agriculture households who live in urban have a positive impact on income levels. The study also finds that the discrepancy of the income level of several class of households are widen after the liberation of poultry imports.
\end{abstract}

Keywords: import; poultry; income; inequality; input-output analysis

\section{Introduction}

The livestock sector plays an important role for the provision of food and the economy in general in Indonesia. This sector provides livelihoods for 4.24 million workers in Indonesia [1]. From the data of the Ministry of Agriculture it is known that one of the important livestock sub-sector is Poultry, which has largest contribution in the production of meat compared to other sub-sector, which is about 52 percent comes from broiler [1].

In terms of consumption, there is an increase in average consumption of poultry meat in Indonesia, and the consumption is fulfilled by domestic production, especially broiler as the main source of poultry meat [2]. Table 1 shows the production and the consumption of chicken meat of the world's 10 largest consumer of chicken meat in the world. From Table 1, it is displayedthat in 2016 most of these countries have surplus of chicken meat (6 of 10 countries), two countries have deficits and Indonesia has the balance between production and consumption. The largest surplus of chicken meat is occurred in Brazil, in which is about 4.09 million tons. The United States reached 2.92 million tons surpluses.Some of the surpluses countries are also exporting countries of the chicken meat.

Brazil and some countries with such surpluses are keen to enter the Indonesian market, but are inhibitedby Indonesian trade policies, and after filing a lawsuit to the WTO, Brazil has won the case. The potential entry of imported poultry meat could threaten the Indonesian economy as chicken prices in surplus countries are cheaper than domestic prices [3]. The entry of imported chicken meat is fearedto hit the domestic production and threaten employment in the Poultry sector.

exemption of imported poultry may have an impact on environmental damage indirectly since the imported poultry may carry the virus to the

\footnotetext{
Corresponding author: firmansyah@live.undip.ac.id
} 
environment and cause instability of the environment indirectly.

\section{Methodology}

This study examines the impact of imported chicken as the liberation of imports, which reduces the consumption of domestic poultry meat in Indonesia. Furthermore, the study analyzes the impact of the decline in domestic consumption, which means pressure for domestic production - assuming that all poultry production can be absorbed by consumers in the domestic market - and its impact on sectoral and national output and income. In the next stage, the study investigates how the difference in household income gap before and after shock of imports liberation. Subsequently, the study employs an econometric model to determine the effect of import prices on domestic chicken meat consumption, Input-Output (IO) model to measure the impact of decreased domestic chicken consumption on output and income, and the Social Accounting Matrix (SAM) model to measure the impact of household income gap which can be seen at figure 1 .

Figure 1. The Production and Consumption of Chicken Meat of the Top Ten Largest Countries in the World 2016

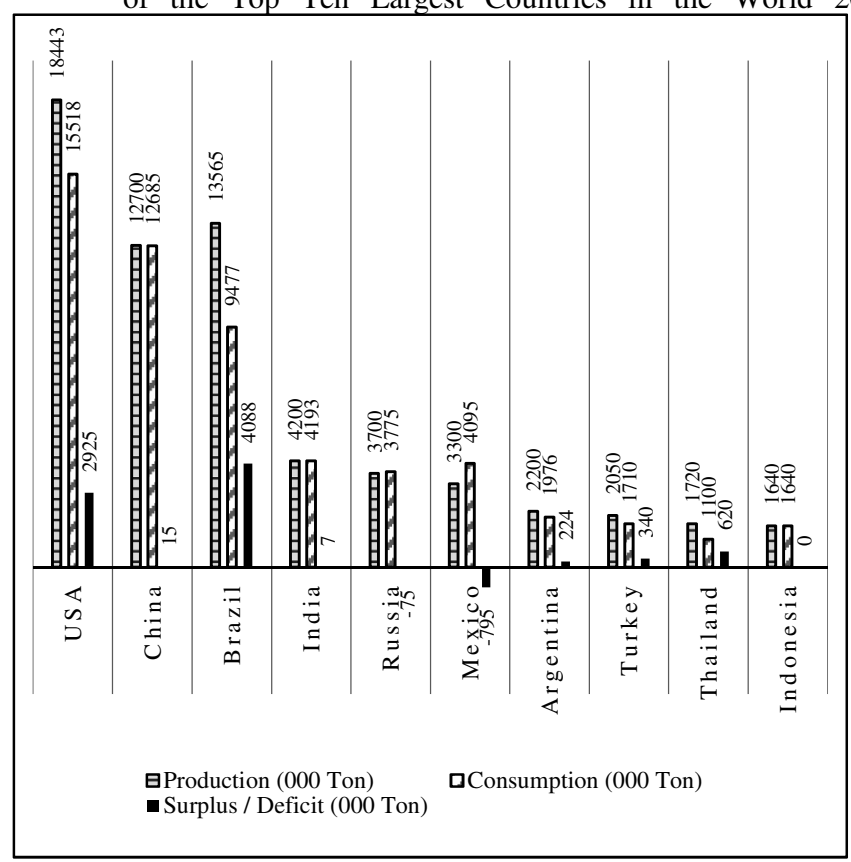

\section{Discussion}

The time series data along 1987-2016 for the eonometric model includes domestic consumption variables of chicken meat (ton / year), domestic price of chicken meat (rupiah/ $\mathrm{kg}$ ), and import price of chicken meat (US cents per pound), from the Ministry of Agriculture and Badan Pusat Statistik (BPS). The data of IO table with the based price transaction of 185 sectors from the 2010 Input-Output (IO) table of Indonesia, the latest IO table were published by BPS [4], and the SAM Table of Indonesia 2008, which the latest SAM table were published by BPS [5]. Sector code list can be seen in 2010 Indonesia IO Table 4 and 2008 Indonesia SAM Table 5.

\section{A. The Development of Shock Scenario}

The econometrics equation due to imports liberation scenario, as follows:

$$
\mathrm{Cut}=\mathrm{a} 0+\mathrm{a} 1 \mathrm{Put}+\mathrm{a} 2 \mathrm{Pmut}+\mathrm{et}
$$

where $\mathrm{Cu}$ is domestic consumption of chicken meat (ton/year), $\mathrm{Pu}$ is domestic price of chicken meat (rupiah $/ \mathrm{kg}$ ), and Pmu is import price of chicken meat (US cents/Pound); $t$ is time, and e is error term.From eq. (1), it is formed the shock for the impact simulation, which is explained in Table I.The decrease of price import by $\mathrm{Rp} 1 / \mathrm{kg}$, decreasess the domestic poultry meat by 699,719 million rupiah. This means that the pressure on domestic poultry production is the same as the decline in domestic consumption.

Input-Output Analysis is a general equilibrium analysis, based on tables in the form of transaction matrices of goods and services, with emphasis on the sectoral production side. Further explanations for the IO analysis and table can be read on Firmansyah [6]. The shock scenario for simulation is developed and then injects in the IO table namely the Poultry and its products sector (code 28$)^{4}$. The impact of the changes in consumption of poultry to sectoral output changes is calculated by the following formula:

$$
\Delta \mathrm{X}=(\mathrm{I}-\mathrm{A})^{-1} \Delta \mathrm{Y}
$$

where $\Delta Y$ represents a vector of changes in the final demand (including consumption) and $\Delta \mathrm{X}$ vector of output change. A is the technological coefficient matrix and $(\mathrm{I}-\mathrm{A})^{-1}$ is Leontief inverse matrix ${ }^{6}$.

Table 1. Simulation scenario of the increase of poultry meat consumption

\begin{tabular}{|l|l|r|}
\hline No & \multicolumn{1}{|c|}{ Point observations } & \multicolumn{1}{|c|}{ Figure } \\
\hline 1 & $\begin{array}{l}\text { Empirical eq. of } \\
\text { regression result }- \text { Pmutis } \\
\text { significantin } \alpha=5 \%\end{array}$ & $\begin{array}{r}\text { Cut }=4.61+ \\
1.68 \text { Put }+\end{array}$ \\
\hline 2 & $\begin{array}{l}\text { Poultry Consumption } \\
\text { Volume (Kg) }\end{array}$ & $1,345,706,000$ \\
\hline 3 & $\begin{array}{l}\text { Elasticity of Import Price } \\
\text { to Domestic Consumption }\end{array}$ & $1.62 \%$ \\
\hline 4 & $\begin{array}{l}\text { Import prices of poultry } \\
\text { meat in 2016 (rupiah/Kg) }\end{array}$ & 31,592 \\
\hline 5 & $\begin{array}{l}\text { Number of poultry meat } \\
\text { in 2016 (millions Rupiah) }\end{array}$ & 688,719 \\
\hline
\end{tabular}

Source: Output estimation

The impact of the policy shocks on sectoral household income is calculated by the following formula: 


$$
\Delta \mathrm{H}=\mathrm{H}_{\mathrm{R}}(\mathrm{I}-\mathrm{A})^{-1} \Delta \mathrm{Y}
$$

Where $\Delta \mathrm{H}$ represents the income changes vector, $H_{R}$ represents income coefficient of sectoral household income [6].

\section{B. The Income Distribution of Households: Social Accounting Matrices Analysis}

Briefly, SAM is a data framework which based on IO tables that summarizes the various socioeconomic and economic variables. The classification of sectors follows the classification in the Indonesia 2008 Social Accounting Matrix (SAM) [7].

The total multiplier of SAM is $M_{a}=\left(I-A_{n}\right)^{-1}$ or the multiplier matrixthat shows the impact of a sector to other sectors, after going through the whole system of SAM, and also called global pressure. $\mathrm{M}_{\mathrm{a}}$ is decomposed to transfer effects, open loop effectsand closed loop effects [8]. The matrix decomposition which is often used is developed by Pyattdan Round [8]:

$$
\mathrm{M}_{\mathrm{a}}=\mathrm{M}_{3} \mathrm{M}_{2} \mathrm{M}_{1}
$$

di mana $\mathrm{M}_{1}=$ transfer multiplier, which shows the effect of one block to itself. $\mathrm{M}_{2}=$ open loop multiplier, which is the effects of one block to other block, and $\mathrm{M}_{3}$ $=$ closed loop multiplier, is the effect of one block to other block, then back to the first block. The formula of M1, M2 and M3 can be read in Firmansyah [7].

\section{Estimation Results and Analysis}

Tables II and III present the simulation results of 185 sector classification of Indonesia 2010 InputOutput, which covers the sectoral and national impacts of output and household income. The results that are presented in the two tables cover the ten sectors whichhave the greatest impact, and special observations on two sectors that impacted largest by the Poultry (code 028). Table IV displays the SAM simulation results of income of each households groups.

It can be seen from Table II, the Poultry sector which experiences the decrease of consumption, have the highest impact of output. The decrease of consumption in poultry industry due to the liberation of imports is directly and indirectly also lead to the decrease of other sector outputs, namely the Sector 072 (Processing Animal Food) and Sector 156 (which one of its activities is motor), as the two other largest impacted sectors, since these two sectors have highly interlinkage to the Sector 072 and 156. The consumption decrease will push the decrease of poultry activities and push the use of animal food and trade in related motor equipment, as the input of Poultry sector. Most of the 10 sectors are the input sector for the Poultry sector. It implies that the backward link (input path) of Sector 028 is higher than the forward link (output path). In the national level, the consumption of Poultry and hasil-hasilnya by 688.719 billion rupiah will decrease the national output by 1.152 trillion rupiah.

Table 2. output impact of the largest sector due to the decrease of poultry consumption (million rupiah)

\begin{tabular}{|l|c|l|r|}
\hline No & Code & \multicolumn{1}{|c|}{ Industries/Sectors } & \multicolumn{1}{c|}{$\begin{array}{c}\text { Output } \\
\text { changes }\end{array}$} \\
\hline 1 & 028 & Poultry and it products & 691,480 \\
\hline 2 & 072 & Processing animal food & 193,152 \\
\hline 3 & 156 & $\begin{array}{l}\text { Trade besides car and } \\
\text { motorcycles }\end{array}$ & 73,598 \\
\hline 4 & 002 & Corn & 39,646 \\
\hline 5 & 001 & Paddy & 23,884 \\
\hline 6 & 061 & Other flour & 16,712 \\
\hline 7 & 058 & Animal oil and vegetable oil & 7,889 \\
\hline 8 & 095 & Oil and gas refinery products & 6,781 \\
\hline 9 & 020 & Palm & 6,061 \\
\hline 10 & 063 & Rice milling and rice harvesting & 5,791 \\
\hline & & National & $1,152,248$ \\
\hline
\end{tabular}

Source: Output simulation

Table III displays the largest decrease in sectoral household income due to decrease of the consumption of Sector 028 . Other sectors that have the largest impact in income, almost in line with the impact of output, i.e. Sector 072 , Sector 156, and so on. In addition to having the high linkage to the Sector 072 and Sector 156, these sectors also have higher household income coefficients than other sectors, which indicate that they have more labor-intensive than other sectors. In the national level, the income will decrease by 312.326 billion rupiah.

Table 3. impact of household income of the largest sector due to decrease of poultry consumption (million rupiah)

\begin{tabular}{|r|c|l|c|}
\hline No & Code & \multicolumn{1}{|c|}{ Industries/Sectors } & Income changes \\
\hline 1 & 028 & Poultry and it products & 207,480 \\
\hline 2 & 072 & Processing animal food & 43,370 \\
\hline 3 & 156 & Trade besides car and motorcycles & 19,252 \\
\hline 4 & 002 & Corn & 6,686 \\
\hline 5 & 001 & Paddy & 5,135 \\
\hline 6 & 061 & Other flour & 3,653 \\
\hline 7 & 058 & Oil and gas refinery products & 2,317 \\
\hline 8 & 020 & Palm & 2,052 \\
\hline 9 & 170 & Financial and banking services & 1,357 \\
\hline 10 & 063 & Rice milling and rice harvesting & 1,322 \\
\hline \multicolumn{3}{|c|}{ National } \\
\hline
\end{tabular}

Source: Output simulation

Table 4. income distribution pre and post of injection/shock (billion rupiah)

\begin{tabular}{|c|l|r|r|}
\hline \multirow{2}{*}{$\begin{array}{c}\mathrm{N} \\
\mathrm{o}\end{array}$} & \multicolumn{1}{|c|}{ Households group } & \multicolumn{2}{|c|}{ Income } \\
\cline { 2 - 4 } & Pre shock & $\begin{array}{c}\text { Post } \\
\text { shock }\end{array}$ \\
\hline 1 & Household : Agriculture : & $71,632.1$ & $71,715.9$ \\
& Workers & 8 & 4 \\
\hline
\end{tabular}




\begin{tabular}{|c|l|r|r|}
\hline 2 & Household : Agriculture : & $101,984$. & $102,092$. \\
& Land Owners : 0,0 - 0,5 Ha & 27 & 38 \\
\hline 3 & Household : Agriculture : & $51,548.4$ & $51,604.2$ \\
& Land Owners : 0,5 - 1,0 Ha & 1 & 3 \\
\hline 4 & Household : Agriculture : & $54,851.8$ & $54,910.1$ \\
& Land Owners : > 1,0 Ha & 0 & 8 \\
\hline 5 & Household : Non & & \\
& Agriculture: Rural : Low & $113,332$. & $113,435$. \\
& Income & 83 & 91 \\
\hline 6 & Household : Non & & \\
& Agriculture: Rural : Non & $51,178.7$ & $51,229.2$ \\
& workers\&Unspecified & 2 & 1 \\
\hline 7 & Household : Non & & \\
& Agriculture: Rural : High & $103,792$. & $103,896$. \\
& Income & 57 & 05 \\
\hline 8 & Household : Non & & \\
& Agriculture: Urban : Low & $180,850$. & $180,988$. \\
& Income & 37 & 21 \\
\hline 9 & Household : Non & & \\
& Agriculture: Urban : Non & $72,474.4$ & $72,536.5$ \\
& workers\&Unspecified & 1 & 3 \\
\hline 1 & Household : Non & & \\
0 & Agriculture: Urban : High & $186,837$. & $187,004$. \\
& Income & 94 & 11 \\
\hline & Coefficient of variation & 0.507 & 0.507 \\
\hline
\end{tabular}

Source: Output simulation

Note: The classification of households follows the 2008 Indonesia SAM table ${ }^{5}$

Table 4. shows that the highest affected households due to the decrease of domestic poultry consumption is non-agriculture high income households, i.e. households engaged in trading. From the simulation results, it is known that the pre and post injection/shock, the income distribution is similar, which is indicated by the value of coefficient of variation. That is, the distribution of income is not getting lame or getting better with the liberation of Poultry import

\section{Conclusion}

The fall in domestic consumption which is possibly occurred due to the low import prices, can be interpreted as a part of domestic production that is taken over by the import supply in the domestic poultry meat market. As the result, the domestic production declines and the threat to domestic production reduction in the domestic poultry sector is real.

The direct and indirect impacts of import liberation through the domestic consumption decrease in Poultry are also suffered highest by sectors which has highest interlinkage with the Poultry sectors, such as Processing Animal Food as the supplier of food for poultry. From the impact rankings, the sectors which preserve inputs for the poultry and have the greatest impact in comparison with user-output sectors. It is reasonable because the output of the Poultry are largely the final product that is consumed by people.

Regarding the distribution income of household groups, the inflow of poultry from abroad dos not cause the changes in income variation between household groups. The variation of households income pre and post of liberation of imports shock are the same.

The implication of the simulation results are the needed of a systemic policy that also supports the sectors which preserve input for Poultry sector - which strengthens the domestic sector - as the policies which increase the output, consumption and export of poultry, as well as benefit the sector that preserve the inputs for poultry sector.The core policy in Poultry sector aims to improve the competitiveness of the sector, especially to strengthen the position of the domestic market, since the domestic prices are more expensive than international prices indicate that the fundamentals of this sector is fragile.

\section{References}

1. Kementerian Petanian Republik Indonesia, Rencana Strategis Kementerian Pertanian Tahun 2015-2019, (2015).

2. Kementerian Pertanian Republik Indonesia, Outlook Daging Ayam Komoditas Pertanian Subsektor Peternakan, (2016).

3. Liputan6.com, Kalah di WTO Paha Ayam Impor bakal banjiri Indonesia, (2016).

4. Badan Pusat Statistik, Tabel Input Output Indonesia 2010, Jakarta, (2015).

5. Badan Pusat Statistik, Sistem Neraca Sosial Ekonomi 2008, Jakarta, (2010).

6. F. Firmansyah, Operasi Matrix dan Analisis InputOutput (I-O) untuk Ekonomi: Aplikasi Praktis dengan Microsoft Excel dan MATLAB, Semarang, (2006).

7. F. Firmansyah, Analisis Pola Pendapatan Rumah Tangga Pertanian Pra dan Pasca terjadinya Krisis Ekonomi di Indonesia: Aplikasi Multiplier Decomposition pada Sistem Neraca Sosial Ekonomi 1995-1999, (Jurnal Ekonomi Pembangunan, Vol 5, pp.1-31, 2004).

8. G. Pyatt, J.I. Round, Accounting and Fixed Price Multiplier in a Social Accounting Matrix Framework, (A World Bank Symposium Social Accounting Matrix A Basic for Planning, Washington, 1985). 